\title{
Efficacy and safety of icotinib in patients with brain metastases from lung adenocarcinoma [Corrigendum]
}

Xu J, Liu X, Yang S, Zhang X, Shi Y. OncoTargets and Therapy. 2016;9:2911-2917.

On page 2911, the affiliation was listed as Department of Internal Medicine, Cancer Hospital, Chinese Academy of Medical Sciences, Beijing, People's Republic of China.
It should have been Department of Medical Oncology, Beijing Key Laboratory of Clinical Study on Anticancer Molecular Targeted Drugs, National Cancer Center/Cancer Hospital, Chinese Academy of Medical Sciences and Peking Union Medical College, Beijing, People's Republic of China.
OncoTargets and Therapy is an international, peer-reviewed, open access journal focusing on the pathological basis of all cancers, potential targets for therapy and treatment protocols employed to improve the management of cancer patients. The journal also focuses on the impact of management programs and new therapeutic agents and protocols on

\section{Dovepress}

patient perspectives such as quality of life, adherence and satisfaction. The manuscript management system is completely online and includes a very quick and fair peer-review system, which is all easy to use. Visit http://www.dovepress.com/testimonials.php to read real quotes from published authors. 